\title{
ET DYSTERT JUBILEUM - LANDSFENGSLET FOR KVINNER 100 ÅR
}

\author{
Av Vegard Ellingsen
}

I fjor er det 100 år siden vi fikk det første landsfengslet for kvinner i Norge. Det var det tidligere Christiania tukthus i Storgaten 33 som i 1881 ble tømt for mannlige innsatte. Ved Kronprinsregentens Resolusjon av 29 juni ble det bestemt at »Christiania Tugthus fremtidig skal være en Anstalt til Optagelse af Kvindefanger fra hele Riget«.

Jeg skal i denne artikkelen forsøke å belyse bakgrunnen for opprettelsen av den første rene kvinneanstalten i Norge og noen trekk ved dens utvikling fram til i dag. Denne framstilling av kvinnefengslets historie vil forsøksvis avdekke den ringe oppmerksomhet de kvinnlige fanger ble til del da som nả. Et hovedsynspunkt vil være å se kvinnene som en utpreget »rest«kategori innen fengselsvesenet. Økonomiske hensyn og ledige bygninger har bestemt kvinnenes fengselsvilkår, - ikke behandlingstanker eller hensynet til kvinners spesielle situasjon.

De historiske aner til det første kvinnefengsel i Norge finner vi i Danmark. Christian V's Norske Lov av 1688 omtaler arbeid i "Spindehuset« i København som frihetsstraff for kvinner. I årene 1735-89 ble tukthus opprettet i Trondhjem, Christiania, Bergen og Christiansand. Disse var i utgangspunktet tenkt drevet etter lønnsomhetsprinsipper ved at byens borgere fikk overdratt driften, gjerne kombinert med monopol på fremstilling av enkelte vareslag. Dette ble imidlertid ingen økonomisk suksess og de private interesser trakk seg tidlig ut. Tukthusenes opprettelse føyer seg også inn $\mathrm{i}$ et europeisk mønster. På kontinentet har tukthusenes oppkomst på 1600-tallet blitt satt i sammenheng med de store sosiale og økonomiske endringer i samtiden. Foydalsamfunnets oppløsning og religionskrigene bidro til framveksten av et landsbygdproletariat og store mengder løsgjengere, tiggere og andre arbeidslese som kom i drift inn mot byene.

For merkantilismen og senere kapitalismen som samfunnssystem representerte dette et ordensmessig og politisk problem og innesperringen framsto som en løsning. Det er hevdet at tukthuset senere fikk sin funksjon utformet av ønsket om å disiplinere arbeiderklassen og dempe den tiltagende sosiale uro under kapitalismen. Dvs. en renovasjonsfunksjon hvor tukthusene fungerte som oppsamlingssteder hvor grupper av ulønnsomme, ikke bidragsytende ble holdt borte fra det positive, i betydningen produktive, samfunn. I tillegg er det pekt på den økende bruk av fri- 
hetsstraff til erstatning for de gamle straffeformer, reformasjonen og dens strengere syn på moral og usedlighet, og lovendringer som kriminaliserte nye forhold. Samtidig inneholdt ideologien omkring tukthusene strømninger av religiøs art og tanker om elementær fattigforsorg.

I sum synes dette å styrke hypotesen om en sammenheng mellom samfunnsøkonomiske interesser og innesperringen. I tråd med dette kan tukthusenes funksjon i Europa i perioden sees som konjunkturavhengig med en "lønnsomhetsfunksjon" utformet av de rådende økonomiske krefter. Senere utviklet til et forhold av mer indirekte art etter mer utvidede og langsiktige vurderinger.

Tukthusene i Norge endret også karakter. Anstaltene gikk over fra å være tvangsarbeidshus og samle-anstalter for fattige til å bli straffeanstalter for lovbrytere av begge kjonn. En utvikling fullført dels ved lovendringer, dels ved endring av klientellet tidlig på 1800-tallet.

Ved Konglig Resolusjon av 1741 »Anordning om Tugthusets Indrettelse i Christiania og de Fattiges Forpleining i Aggershus Stift« ble det gitt utførlige instrukser om tukthusene og fattigvesenets ordning. Bl.a. ble det bestemt at tukthuset skulle romme alle kvinner dømt til straffarbeid. Dette var et brudd med stiftsinndelingen slik at kvinner fra hele landet idømt frihetsstraff for grovere forbrytelser skulle utstå straffen i Christiania tukthus. Det var således tendenser til en "snik institusjonalisering a av tukthuset til landsfengsel-funksjon allerede fra midten av 1700-tallet.

Tukthusets overgang fra korreksjonsanstalt til straffeanstalt $\mathrm{i}$ siste halvdel av det 18århundre hadde en rekke forutsetninger. Fengselsstraff avløste i hovedsak de andre straffearter. Samtidig ble tukthuset fritatt fra å tjene som anstalt for andre grupper innsatte. Arresthusenes utbyggelse sto her sentralt i avlastningen av betlere, løsgjengere o. a. Lovendringer og tilveksten i lover, samt utstedelsen av en rekke reskript, forordninger og plakater kriminaliserte nye forhold og medførte endringer av anstaltens klientell fra lemmer til fanger. Dette var fundert på endrede sosiale strukturer og økonomiske forhold i samfunnet og utvidet innesperringens grunnlag og funksjon.

Norges anstaltsvesen gjennomgikk på 1800-tallet en spesialisering og rasjonalisering. Sinnsyke- og fattiglovgivningen illustrer dette. Generelt uttrykt kan vi si at det 19 århundre frambragte et mer differensiert kontroll-apparat. Eller om vi velger en annen synsvinkel, en tiltagende utbygging av velferdsstatens omsorgsvesen. I reformarbeidet innen fengselsvesnet står Straffeanstaltkomisjonens innstilling av 1841 sentralt. Foruten å kritisere de rådene forhold innen anstaltsvesnet påpekte den en nødvendig sanering og rasjonalisering av de gamle tukthus og slaverier (festninger). Kommisjonen anbefalte oppføring av 7 nye fengsler etter Philadelphia modellen (Bodsfengsels systemet) hvorav en ren kvinneanstalt. Det ble ikke ansett nødven- 
dig med en særlig type fengsel for kvinner. Den radikale isolasjonen, manglende arbeidssysselsetting og strenge kontroll som systemet innebar var egnet til å få begge kjønn til å angre sine synder og søke »bot og bedring «.

Det håndfaste resultat av komisjonens arbeid var Bodsfengslet som sto ferdig i 1851. Samtidig foregikk såvel forut som deretter en kraftig beskjæring i antallet anstalter. En utvikling som ble påskyndet ved at straffefullbyrdelse på slaveri og tukthus i 1877 ble likestilt.

Christiania tukthus var tømt for menn i 1881 og omgjort til den første rene kvinneanstalten i Norge. I 1885 ble ensartede betegnelser på slaveriene og tukthusene innført, nemlig straffeanstalt. Christiania tukthus fikk således betegnelsen Straffeanstalten for kvinner i Christiania. Den 31. mai 1900 ble straffeanstalt-betegnelsen erstattet med Landsfengslet for kvinner.

Opprettelsen av kvinneanstalten synes å inngå som en brikke i en større endring av fengselsvesenet, for ikke å si hele vårt anstaltsvesen. En rasjonalisering som dels ble utløst av Straffeanstaltskomisjonens innstilling, dens harde kritikk av de rådende forhold og dens ideer om det framtidige fengselsvesen. Dels var endringene fundert på økonomiske vurderinger. Mange av anstaltene hadde et lite fangebelegg og ble derfor uforholdsmessig dyre å opprettholde.

På den annen side er det ikke funnet noe som tyder på at utviklingen av eget kvinnefengsel var resultatet av en bevisst planlegging i forhold til kvinnenes situasjon. De argumenter som framkom for adskillelse av kjønnene var basert på hensynet til usedligheten i anstalten, der usedligheten ble tolket som en indikator på manglende orden og disiplin i fengslet. Videre argumenterte man utfra en »naturgitt« forståclse av adskillelse og av praktiske hensyn.

Den lave oppmerksomheten som ble de kvinnlige innsatte til del hadde selvfølgelig sammenheng med deres beskjedne antall. De representerte et lite sosialt problem og ble derfor of ret liten offentlig oppmerksomhet. Mot slutten av århundret kom diskusjonen i gang hvorvidt kvinnefanger burde ha særskilte reglementer vedrørende arbeid, disiplin, kost etc. Dvs. om det ikke var mer hensiktsmessig å utarbeide et eget straffesystem for kvinner. Emnet sto bl. a. sentralt på fengselskongressen i Paris i 1895.

En tydlig kontinuitet uttrykkes i overgangen fra tukthus til kvinnefengsel ved en administrativ, byggningsmessig og driftsmessig institusjonsarv.

Kontinuitet, om enn i en annen form preget også kontrollapperatets utvidelse. Kvinnefengslet inngikk i en anstaltsmessig kontinuitet hvor den ene anstalt grenset opp til den neste. $\mathrm{Og}$ hvor kvinnefengslet ikke representerte en løsrevet anstalt men kun en forlengelse av serien af disiplinerende institusjoner. 
Kvinnefengslet var i særlig grad preget av en anstaltsarv og ble egentlig lite delaktig i de fornyelser som fengselsvesenet gjennomgikk. Endringene $\mathrm{i}$ anstaltsstrukturen hadde få virkninger for de kriminelle kvinnene som gruppe. Av langt større betydning var de strafferettslige reformer som medførte betraktlig færre kvinner innesperret.

Dette skyldes bl. a. at anstalten framsto i et etablert institusjonsmiljø. Kvinnefengslet var et eldre tukthus som fysisk ble tømt for menn og hvor kvinnene omsider erstattet menne også i anstaltens ledelse.

I vårt århundre fortsatte den vidre utbyggingen av kontrollapparatet og nye lover kom til, løsgjengerloven, arbeidsskoleloven, vergerådsloven, osv. Fengselsloven av 1903 føyer seg inn i dette mønsteret. Den samlet og utarbeidet ensartede regler for fengslene, administrasjon og fangebehandling.

Straffeloven av 1902 opphevet forskjellen mellom fengsel og straffarbeid og i 1904 overtok staten all drift og ansvar for straffeanstaltene. I 1907 ble det $\mathrm{i}$ landsfengslet innrettet et tvangsarbeidhus for kvinner innsatt etter løsgjengerloven. Samtidig ble kvinnlige tvangsarbeidere fra Chrstiania kommunale tvangsarbeidsanstalt overført dit. Dette kunne gjøres etter de forutgående lovendringer som hadde medført et redusert fangetall og dermed gjort anstalten uforholdsmessig kostbar.

Denne sentralisering synes å stå i motsetning til den rådende tendens til differensiering og spesialisering som gjorde seg gjeldene innen anstaltsvesenet. En utvikling med bakgrunn i den positive skole innen kriminologien som utfra sin deterministiske orientering krevde en individuell behandling. For å imøtekomme kravet om et differensiert behandlingstilbud var oppsplittingen i særreaksjoner og differensiering av klientelet nødvendig. Utviklingen i kvinneanstalten gikk på tvers av denne tendens ved oppsamling av flere kategorier kvinnlige avvikere $i$ en sentral-anstalt.

I diskusjonen om kvinnefengslets fremtidige skjebne sto eiendommens tomteverdi sentralt. Staten gikk mot salg ved flere anledninger. Bl. a. da kommunen ønsket å overta tomten i forbindelse med den vedtatte reguleringsplan. Departementet argumenterte gjennomgående utfra økonomiske vurderinger i sine avslag og viste til manglende bevilgninger til oppførelse av noen ny anstalt. Da tukthuseiendommen først ble solgt i 1936 hadde tomteprisene i Christiania steget betydlig. Samtidig var de øvrige områder innen fengselsvesenet brakt $\mathrm{i}$ orden, Bodsfengslet var utvidet ved kjøp av den tilgrensende eiendom (»Bayern«), tvangsarbeidshussystemet var realisert (Opstad 1915) og endringene i fengselsloven var sanksjonert.

I 1936 ved salg av tukthuset ble det bestemt att nytt kvinnefengsel skulle oppføres på Ila i Bærum. Dette var beregnet til ca. 100 innsatte, og med adskilte avdelinger for fanger og tvangsarbeidere. Som en midlertidig ord- 
ning ble anstaltens belegg i 1938 overført til Bredtveit i Østre-Aker. Dette var et tidligere lærehjem for unge gutter som i 1929 var overlatt fengselsvesenet.

Under krigen ble Bredtveit tatt i bruk som politisk fengsel, og i 1941 ble det ordinære kriminelle belegget overført til et tidligere distriktsfengsel på Sel i Gudbrandsdalen.

Den nye anstalten på Ila var beregnet ferdig i 1940 men var ikke tatt i bruk da krigen brøt ut. Tyske myndigheter overtok Ila først som krigsfangeleir for norske offiserer, senere som konsentrasjonsleir for politiske fanger under navnet Grini fangeleier. Under krigen ble det foretatt store utvidelser og nybygginger og anstaltens kapasitet vokste betydlig, en tid var belegget over 5300 .

Etter krigen, fram til 1950 ble Ila brukt til landsviksoppgjøret under navnet Ilebu fengsel. På det tidspunkt det ble aktuelt å tilbakeføre anstalten til det ordinære fengselsvesen viste den seg uegnet til kvinnefengsel pga. sin størrelse og fordi antallet kvinnefanger viste en synkende tendens.

Bredtveit hadde fra 1945 vært brukt som kvinnefengsel ved rettsopgjøret mot landssvikerne. I 1949 ble det fastslått som permanent ordning at kvinnelandsfengslet og arbeidshuset for kvinner skulle innredes på Bredtveit.

Pga. den fortsatte nedgangen i antall innsatte, en halvering fra 1949 til 59 , ble antallet funksjonærer redusert fra 36 til 23. Dette uten hensyn til at forholdene ved anstalten var av spesiell natur. Det var de samme funksjoner som måtte utføres her som ved store fengsler, ofte ved hjelp av mannlig betjening til vakthold, vedlikehold og transport. Dessuten hadde anstalten et meget blandet belegg.

Reduksjonen i antall innsatte førte også til at spørsmålet om en »bedre utnyttelse « av Bredtveit igjen ble fremmet, og igjen ble det besvart med en utvidelse av anstaltens belegg. I 1959 ble Bredtveit utvidet til kretsfengsel for kvinner i Oslo og Akershus (kvinneavdelingen ved Oslo kretsfengsel nedlagt) foruten å være landsfengsel og arbeidshus for kvinner. Følgelig ble belegget mer enn fordoblet fra 1958 til 59.

Det nye fengselsreglementet av 1961 og senere endringer gav nye innsettelsesregler for kvinner. Bl. a. skulle all frihetsstraf over 6 mnd fullbyrdes på Bredtveit, samt kortere straff ilagt i Østre fengselsdistrikt og deler av Søndre.

Etter endringer i løsgjengerloven i 1970 ble arbeidshusavdelingen nedlagt. Samtidig fikk anstalten den offisielle betegnelsen Bredtveit fengsel og sikringsanstalt. Som fengsel skulle anstalten motta kvinner idømt fengselsstraff og varetektsinnsatte fra Oslo, Akershus og Østfold. Som lokalfengsel 
skulle den motta domfelte fra Østre og Søndre fengselsdistrikt og som sikringsanstalt motta kvinner sikret etter straffelovens $\$ 39,1$ e.

Bredtveit må på flere måter sies å være en foreldet anstalt. Anstalten er, på tross av moderniseringstiltak, rent bygningsmessig så gammeldags at forbedringene har sine fysiske grenser. Men forbedringer er ikke bare et bygningsteknisk spørsmål. Sammenlikner en kvinneanstalten med våre mannsanstalter og f. eks. kvinnefengslene i Danmark (ordningen ved Horserød og Ringe statsfengsler) fremstår Bredtveit som "gammelmodig « mht. straffeinnholdet og de innsattes tilbud om undervisning og arbeid.

Siden Bredtveit fengsel og sikringsanstalt er det eneste kvinnefengsel i Norge rommer anstalten mange ulike kategorier innsatte. Kvinner dømt for svært ulike forbrytelser, fra promilledømte til den groveste kriminalitet, varetektsinnsatte, kvinner med høyst ulik bakgrunn og tidligere kriminell »karriere « er alle innesperret $\mathrm{i}$ en lukket anstalt. De sikkerhetsmessige foranstaltninger og interne bestemmelser er nødvendigvis innrettet etter det hardest belastede klientell. At dette er en streng reaksjon og for flere kategorier unødvendig merbelastning ble også uttrykt i kriminalmeldinga (St. meld. nr. 104 1977-78). Den manglende mulighet til et differensiert straffesystem stiller kvinnefangene $\mathrm{i}$ en åpenlyst dårligere situasjon enn mannlige fordi en del av kvinnene er kvalifisert til å sone i et »åpent« fengsel. St. meldingen anbefalte også et mer gradert system for kvinners frihetsberøvelse.

Årsaken til at kun menn idag utstår straff i et slikt system ble antydet i det faktum at kvinnene var så få $\mathrm{i}$ antall at selv ikke kapasiteten på Bredtveit udnyttes maksimalt. Hvis denne forklaringen godtaes innebærer det at økonomiske vurderinger fremdeles står sentralt ved utformingen av straffeinnholdet for innesperrede kvinner.

Vegard Ellingsen

Adresse: Bergliensgat. 11, Oslo 3. 